\title{
ANATOMICAL CHARACTERIZATION OF WOOD MARKETED AS "TAUARI" (LECYTHIDACEAE) IN PARÁ STATE, BRAZIL
}

\author{
Joielan Xipaia dos Santos ${ }^{1 *}$, Helena Cristina Vieira, Eliane Lopes da Silva², Graciela Inés Bolzon de Muñiz ${ }^{2}$, \\ Alisson Rodrigo Souza Reis ${ }^{3}$, Silvana Nisgoski ${ }^{2}$
${ }^{1}$ Universidade Federal do Paraná, Programa de Pós-Graduação em Engenharia Florestal, Curitiba, Paraná, Brasil. E-mail: joilan87xipaya@gmail.com*, lenacristin@gmail.com, eliane0103@gmail.com.
${ }^{2}$ Universidade Federal do Paraná, Departamento de Engenharia e Tecnologia Florestal, Curitiba, Paraná, Brasil. E-mail: graciela.ufpr@gmail.com, morroni@ufpr.br, silvana.ufpr@gmail.com.
${ }^{3}$ Universidade Federal do Pará, Faculdade de Engenharia Florestal, Campus Altamira, Brasil. E-mail: alissonreis@ufpa.br \\ Received for publication: 12/05/2018 - Accepted for publication: 03/03/2020
}

\begin{abstract}
Resumo
Caracterização anatômica de madeiras comercializadas como "tauari" (Lecythidaceae) no estado do Pará, Brasil. A pressão antrópica sobre os recursos florestais da Amazônia, evidenciada pela exploração ilegal de madeira, contribui para o aumento da lista de espécies da flora brasileira ameaçadas de extinção, como ocorre com algumas representantes da família Lecythidaceae. Desta forma, visando contribuir com a fiscalização no controle do corte ilegal das árvores, o objetivo deste trabalho foi identificar e caracterizar amostras de madeiras comercializadas como "tauari", fornecendo subsídios para a separação a nível de espécie. As amostras foram obtidas em 15 serrarias de 10 municípios do estado do Pará. A identificação foi confirmada pela comparação com amostras padrão dos acervos das xilotecas do Museu Paraense Emílio Goeldi e da Embrapa Amazônia Oriental. Das vinte amostras analisadas, três foram identificadas como não pertencentes ao grupo "tauari": Eschweilera sp. (matamatá-branco), Cedrela sp. (cedro) e Erisma uncinatum (cedrinho). As demais amostras pertenceram ao grupo "tauari" com três espécies: Couratari stellata, C. oblongifolia, $C$. guianensis. Todas as espécies pertencentes à família Lecythidaceae, incluindo Eschweilera sp. apresentaram semelhanças na estrutura anatômica da madeira, tanto a nível macro como microscópico. Conclui-se que a adoção de um único nome popular pelas empresas madeireiras no estado do Pará para designar madeiras do grupo "tauari" mascara as informações sobre a diversidade de espécies comercializadas, compromete o uso final da madeira e a relação de confiabilidade entre comprador e vendedor.

Palavras-chave: Identificação, Couratari, Eschweilera, Erisma, Cedrela
\end{abstract}

\begin{abstract}
A anthropogenic pressure on the forest resources of the Brazilian Amazon, partly caused by illegal logging, has contributed to increase the list of endangered Brazilian flora species, as is the case of some representatives of the family Lecythidaceae. In this way, aiming to contribute to the control of the illegal cutting of the trees, the objective of this study was to identify and characterize samples of wood marketed as belonging to the "tauari" group, in order to provide support for species-level identification. Samples were obtained from 15 sawmills in 10 municipalities in the state of Pará in June and July 2016. The species identification was confirmed by comparison with standard samples from the wood collections of Museu Paraense Emílio Goeldi and Embrapa Amazônia Oriental. Three samples were identified as not belonging to the "tauari" group: Eschweilera sp. (matamatá-branco), Cedrela sp. (cedro) and Erisma uncinatum (cedrinho). The other 17 samples belonged to the "tauari" group with three distinct species: Couratari stellata, C. oblongifolia and C. guianensis. All species from Lecythidaceae family presented similarity in anatomical structure of wood, at macroscopic and microscopic level. The adoption of a single popular name by logging companies in the state of Pará to designate timber from the "tauari" group masks information about the diversity of species traded and compromises the end use of timber and the trust between buyer and seller.
\end{abstract}

Keywords: Identification, Couratari, Eschweilera, Erisma, Cedrela

\section{INTRODUCTION}

Brazil stands out in the world scenario for having extensive native forest areas (IBÁ, 2016), containing an expressive fraction of the world diversity of fungi and plants (9.5 to $9.9 \%)$, with 18,932 endemic tropical tree species, that is, one of the highest rates of endemism (46.2\%) on the planet (FORZZA et al., 2010). However, Martinelli and Moraes (2013) estimated 87 tropical tree species threatened with extinction, 90 with insufficient data and 142 not threatened, but considered of interest for conservation and research.

FLORESTA, Curitiba, PR, v. 50, n. 3, p. 1421 - 1429, jul/set 2020.

Santos, J. X. et.al.

ISSN eletrônico 1982-4688

DOI: 10.5380/rf.v50 i3. 59399 
In recent years, with technological development and problems with fossil fuels, pressure on native forest has increased, in all world, including Brazil, with highlights for legal Amazon, which presented 7,421 kilometers degraded only in October 2017 (FONSECA et al., 2017). So, with the objective of reduce illegal commerce of native wood is necessary a correct identification of tropical trees, especially in Brazilian Amazon, in function of considerable number of species with wood commerce potential (CANDIAN; SALES, 2009).

In this context are present some tropical species marketed popularly as "tauari", being related in three genera of Lecythidaceae family: Allantoma, Cariniana e Couratari (PROCÓPIO; SECCO, 2008). In general, this species is large, for example, Couratari stellata and Cariniana micrantha trees are considered biggest trees in family, reaching $60 \mathrm{~m}$ of height. Also, genera Couratari present principal occurrence in North of Amazon, with 53\% of species (MORI, 1990) and species Couratari guianensis, C. oblongifolia, C. stellata and Cariniana micrantha are between ten woods more commercialized in Brazil, as logs and sawn wood (NAHUZ, 2013).

The database of the System of Commerce and Transport of Forest Products in Pará (SISFLORA-PA) shows sales of almost a million cubic meters of wood from the "tauari" group between January 1, 2006 and February 21, 2016 (SEMAS-PA, 2016). The importance of this group is justified because wood is moderately smooth cut, allowing good finishes characteristics, being applied in civil construction, also for both internal and external market (PAULA; COSTA, 2011).

In Brazilian Amazon, identification of species from "tauari" group, principally in forest inventories is a problematic factor in function of diversity and diverse origins of material, being frequently grouped in the same species (BERNAL et al., 2011; SEMAS-PA, 2016). The commerce of many species in a single name or derivations, for example, as "tauari": Couratari guianensis, C. oblongifolia C. pulchra, C. stellata, C. multiflora, C. tauari, C. macrosperma and Cariniana micrantha has also being reported (IBAMA, 1991).

So, adequate methods for species identification are imprescindible. Anatomical characterization is considered the most efficient technique for identification of wood species, because it relates anatomic and morphologic characteristics of unknown wood with standard samples stored in registered wood collections (GASSON, 2011).

Based on above information's, and the relevance of "tauari" species in Amazon and wood market, the objective of this study was to identify and characterize wood samples marketed as "tauari" in Pará state to species level by macroscopic and microscopic wood analyses.

\section{MATERIAL AND METHODS}

Twenty samples of boards marketed as "tauari" with approximately 50x20x5 cm (length, width and thickness), were randomly collected in 15 sawmills located in 10 municipalities of the eastern Amazonian state of Pará (Figure 1). However, it was not possible to determine whether sawmill timber was or was not derived from Sustainable Forest Management Plans (PMFS). The samples were analyzed at the Wood Anatomy and Quality Laboratory of the Federal University of Paraná. For anatomic characterization, samples with dimensions of $5 \times 5 \times 2 \mathrm{~cm}$ (length, width and thickness), were extracted from each board. The collected samples were compared with reference samples from wood collections of the Xiloteca (Walter A. Egler collection) of Museu Paraense Emílio Goeldi and of Embrapa Amazônia Oriental. 


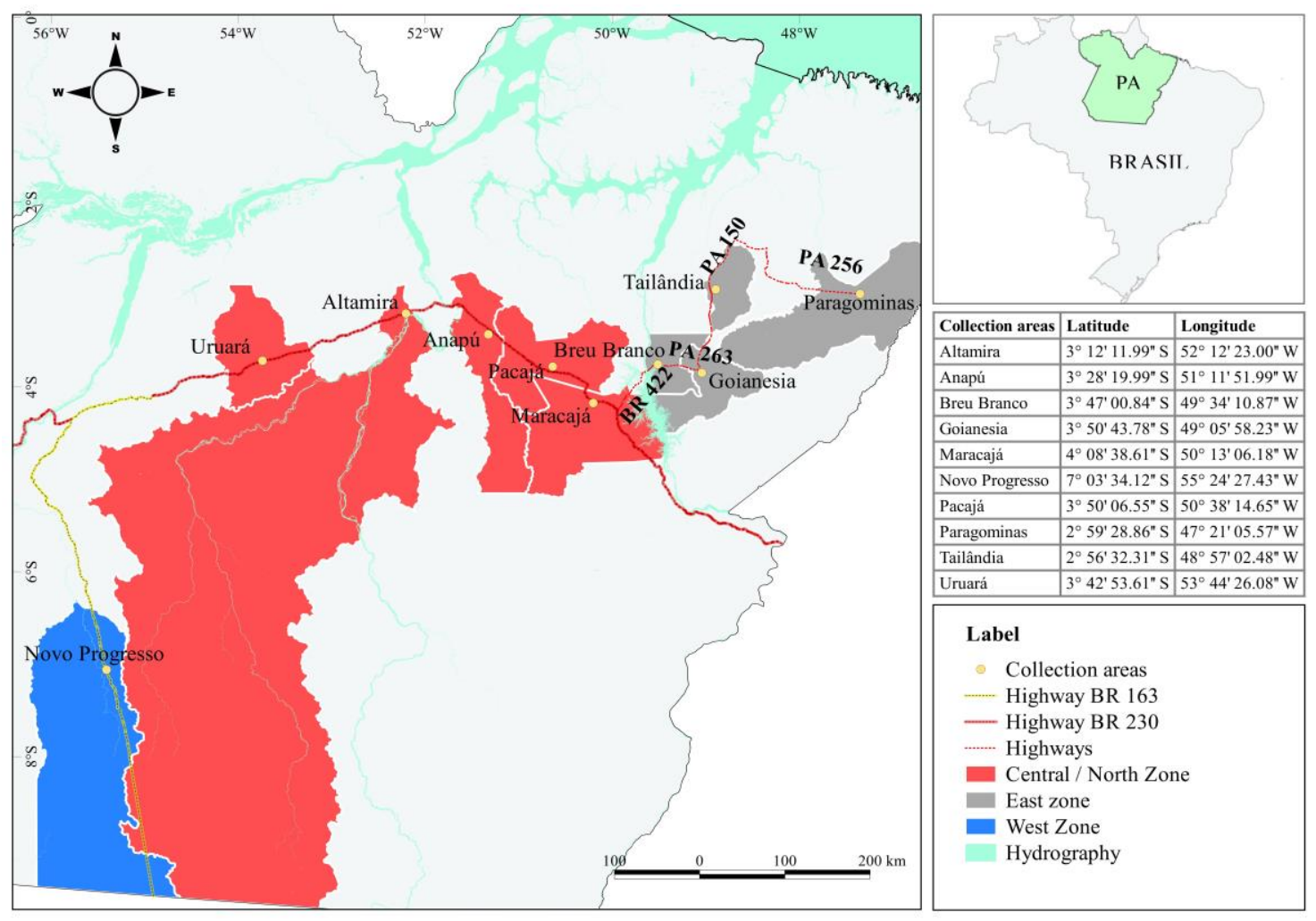

Figure 1. Map of municipalities where samples were collected in Pará state.

Figura 1. Mapa com a localização dos municípios de coleta no estado do Pará.

\section{Anatomical characterization}

Macroscopic and microscopic characterization was based on standards from the International Association of Wood Anatomists (IAWA, 1989), INTKEY interactive key of general and macroscopic characteristics of commercial woods from Brazil (CORADIN et al., 2011), and index cards of anatomical description of wood samples from the Walter A. Egler wood collection at Museu Paraense Emílio Goeldi.

For macroscopic characterization, samples were oriented transversally, tangentially and radially. The surface was polished with a microtome slicing, to reveal anatomical structures. With a 10x magnifying glass, the anatomical structures were evaluated and compared with the reference samples. Images of transversal sections were obtained with a Zeiss Discovery V12 stereomicroscope attached to a camera, using the Axio Vision software. Macroscopic description was based on the the following characteristics: i) color; ii) brightness; iii) odor; iv) presence of growth rings; v) visibility and type of axial parenchyma; vi) visibility of rays; and vii) visibility, type, distribution and obstruction of vessels.

For microscopic evaluation, radial, tangential and transversal sections with length of $1.5 \mathrm{~cm}$ were prepared. The material was boiled in water for 3-6 hours per day for two weeks because of its hardness. Histological sections with $25 \mu \mathrm{m}$ were obtained with a Zeiss-Hyrax S50 microtome. The sections were stained with acridine crisoid in red and astra blue. The material remained in $70 \%$ alcohol until analysis.

Temporary slides were prepared to evaluate the following structural characteristics: i) ray frequency; ii) ray height; iii) ray width in cells and in micrometers; iv) vessel frequency; and v) tangential vessel diameter. For each characteristic, 30 data were obtained. Images from transversal and tangential sections were obtained in with a Zeiss Discovery V12 stereomicroscope coupled to a camera, and the Axio Vision software was used to measure the microscopic features.

Quantitative statistics were calculated for each anatomical characteristic: i) ray frequency; ii) ray height; iii) ray width in cells and in micrometers; iv) vessel frequency; and v) tangential vessel diameter. Means were assessed using Scott-Knott (95\% probability) and deviation of each were verified. 


\section{RESULTS}

Eighteen samples were identified as belonging to four species of Lecythidaceae: Couratari stellata (6 samples), C. oblongifolia (7 samples), C. guianensis (4 samples) and Eschweilera sp. (1 sample). One sample was identified as Cedrela sp. (Meliaceae), otherwise popularly designated as cedro, and another as Erisma uncinatum (Vochysiaceae), normally designated as cedrinho. Thus, we identified four genera marketed as "tauari": Couratari, Erisma, Cedrela and Eschweilera. For species Cedrela sp., and Erisma uncinatum analysis of anatomical structure was done only at macroscopic level, because are species that present distinct features from Lecythidaceae family, as semi-ring porous and axial parenchyma marginal (Cedrela sp.), and axial parenchyma in bands (Erisma uncinatum). Therefore, genera Cedrela and Erisma, were identified and discriminated more easily than samples from genera Couratari and Eschweilera, which are much similar even at microscopic level and distinction were difficult.

In general, the species identified based on macroscopic characteristics (Figure 2) could be separated into four groups according to heartwood color: pinkish beige (Cedrela sp., Figure 2a), reddish brown (Erisma uncinatum, Figure 2b), dark yellow (Couratari oblongifolia, Figure 2c), and yellow and grey (Couratari stellata, Couratari guianensis and Eschweilera sp., Figures 2d, 2e, 2f). Wood odor was perceptible only in samples of Cedrela sp. and Couratari oblongifolia.

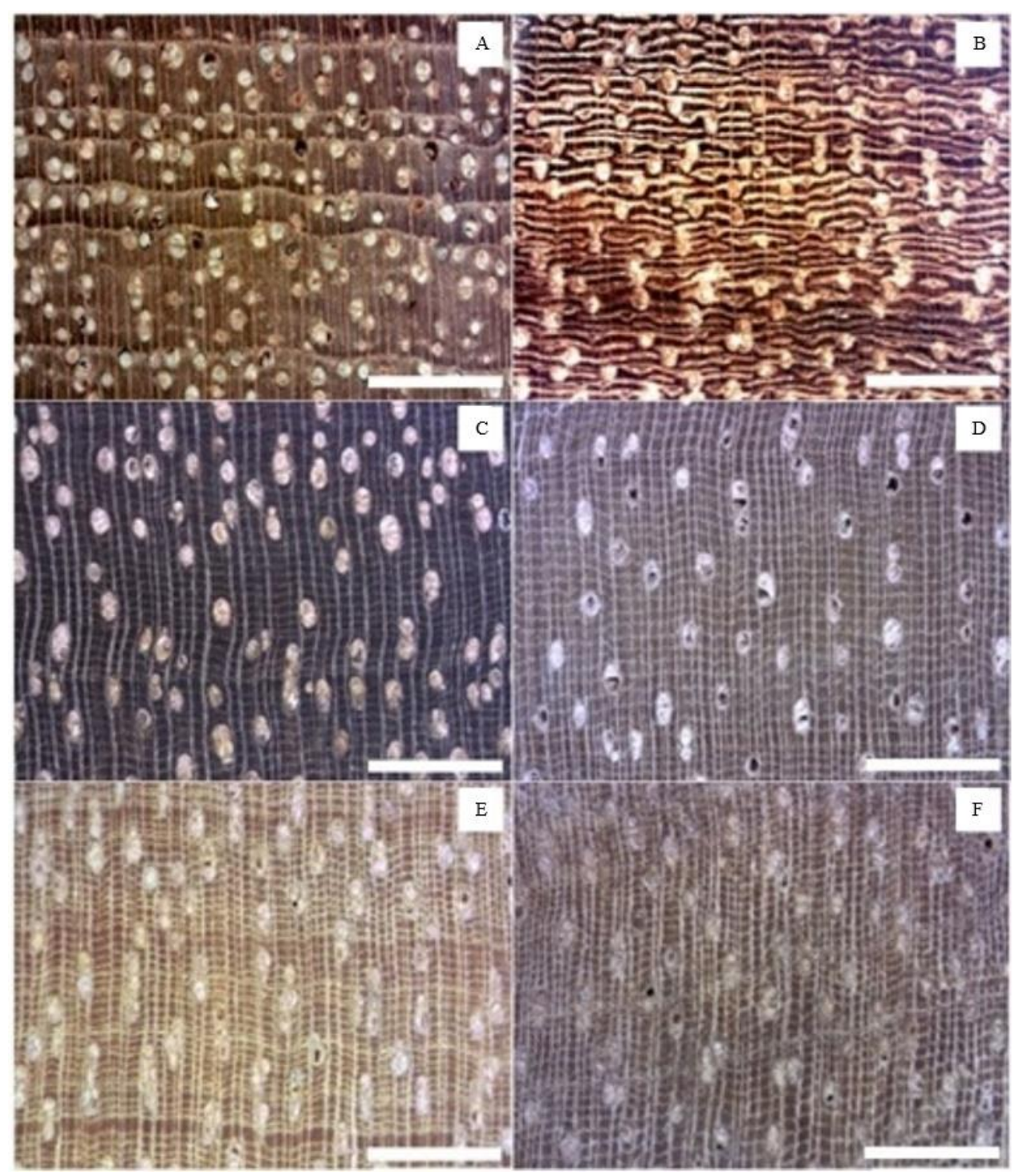

FLORESTA, Curitiba, PR, v. 50, n. 3, p. 1421 - 1429, jul/set 2020.

Santos, J. X. et.al.

ISSN eletrônico 1982-4688

DOI: 10.5380/rf.v50 i3. 59399 
Figure 2. Macroscopic images of transversal sections of Cedrela sp. (A); Erisma uncinatum (B); Couratari oblongifolia (C); Couratari stellata (D); Couratari guianensis (E); and Eschweilera sp. (F). Scale bar $=2 \mathrm{~mm}$. This figure is in color in the electronic version.

Figura 2. Imagem macroscópica dos cortes transversais de Cedrela sp. (A); Erisma uncinatum (B); Couratari oblongifolia (C); Couratari stellata (D); Couratari guianensis (E); and Eschweilera sp. (F). Barra de escala $=2 \mathrm{~mm}$.

Growth rings were distinguished by axial parenchyma in marginal bands and semi-ring porous in Cedrela sp., sparsely perceptible in Couratari oblongifolia, C. stellata and C. guianensis, with darker fibrous regions, and indistinct in samples of Eschweilera sp. and Erisma uncinatum.

Axial parenchyma was visible to the naked eye in wide bands in Erisma uncinatum, and in marginal bands in Cedrela sp. In samples of Lecythidaceae, the axial parenchyma was reticulate to scalariform, with bandwidth of 1-2 cells for Couratari oblongifolia, C. stellata and C. guianensis. In the samples of Eschweilera sp., we also observed reticulate axial parenchyma with 2 cell bandwidth, but it differed from the Couratari genera because it was only distinct with $10 \mathrm{x}$ magnification.

Rays were visible to the naked eye on the top and tangential faces in Cedrela sp. and visible with 10x magnification on the top and tangential face in Erisma uncinatum. In the Lecythidaceae species, Couratari oblongifolia, $C$. stellata and $C$. guianensis presented rays visible to the naked eye, thin and numerous, regularly spaced and none storied. Samples of Eschweilera sp. presented rays visible with 10x magnification, which were thin, numerous and irregularly spaced.

Vessels were visible to the naked eye, small to large, with a gradual change from latewood to earlywood, semiring porous, solitary predominant and in radial multiples, with gum deposits present in Cedrela sp. In Erisma uncinatum, vessels were visible to the naked eyes, medium to large, with diffuse porosity, solitary and in radial multiples of 2-3, with tyloses. In species of Lecythidaceae, vessels had diffuse porosity, visible to the naked eye and tyloses were observed. In Couratari stellata, C. oblongifolia and Eschweilera sp., vessels were predominantly solitary, with presence of radial multiples of 2-3. In C. guianensis, solitary vessels and radial vessels in multiples of two were observed in the same proportion.

Regarding microscopic features (Table 1, Figure 3), vessels were circular to oval, with tangential diameter of 157 - $290 \mu \mathrm{m}$, and frequency from 1-5 for all species of Lecythidaceae. In Couratari oblongifolia and Eschweilera sp., prismatic crystals in axial parenchyma were observed. Heterogeneous rays were observed in Couratari oblongifolia, Couratari stellata and Couratari guianensis, body ray cells were procumbent, with one row of square marginal cells, sometimes interrupted by short procumbent cells. In Eschweilera sp., heterogeneous rays also were observed, with body cells procumbent and one square marginal cell. Ray widths were classified as fine (less than $87 \mu \mathrm{m}$ ), ray height was considered low (between 485 and $710 \mu \mathrm{m}$ ), with low frequency (6-10 ray/mm). Store structure, secretor cells, cambial variants and silica were not observed in any sample. All species had simple perforation plates, alternate intervessel and vessel-ray pits similar in size and shape. Fibers with bordered pits were distinct in all species. 


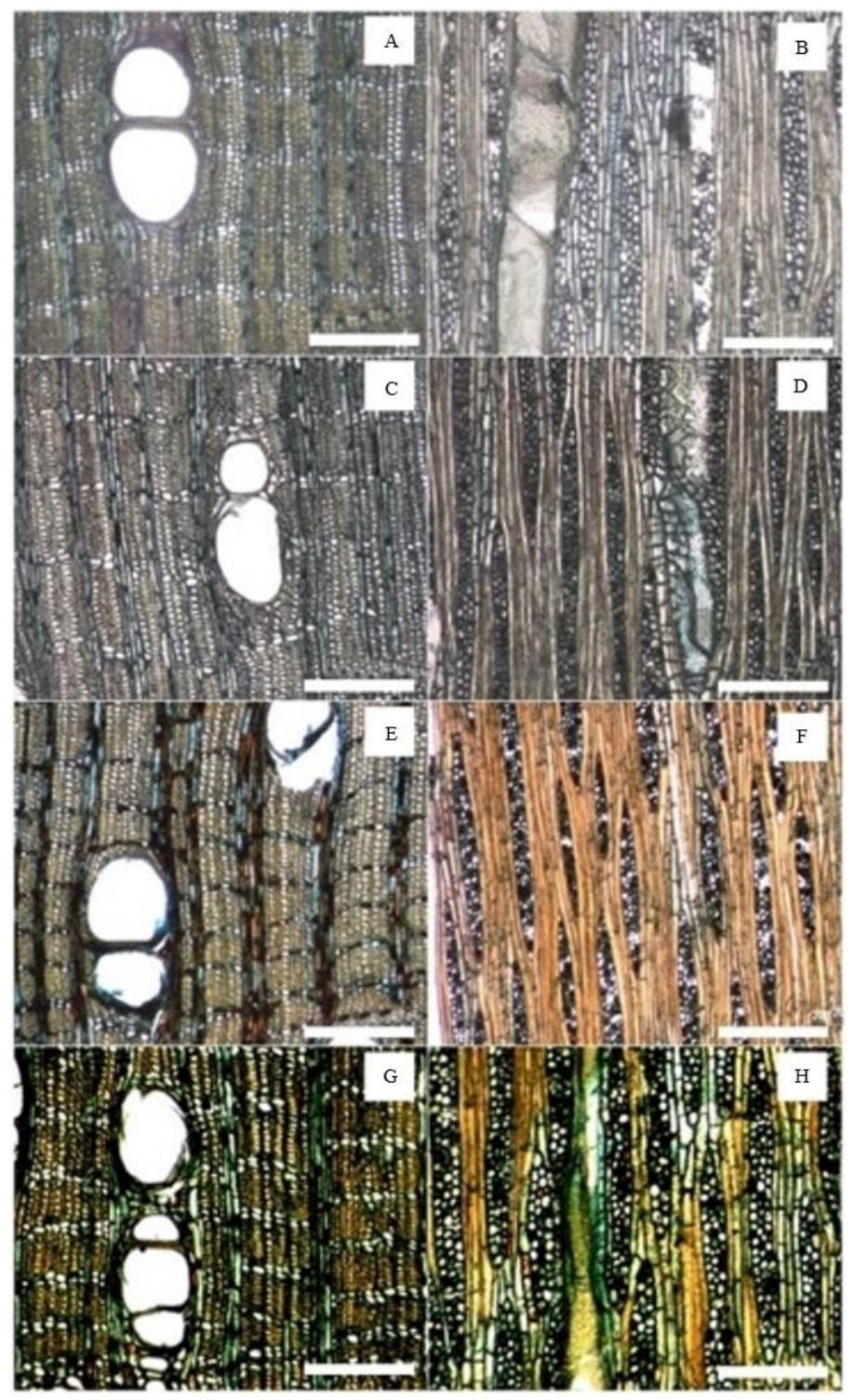

Figure 3. Microscopic images of transversal and tangential sections of Couratari oblongifolia (A, B); Couratari stellata (C, D); Couratari guianensis (E, F); and Eschweilera sp. (G, H). Scale bar $=200 \mu \mathrm{m}$.

Figura 3. Imagens microscópicas dos planos transversais e tangenciais de Couratari oblongifolia (A, B); Couratari stellata (C, D); Couratari guianensis (E, F); and Eschweilera sp. (G, H). Barra de escala = $200 \mu \mathrm{m}$.

Table 1. Microscopic parameters of wood samples from belonging to four species marketed as "tauari", taken from sawmills in several municipalities in Pará state, northern Brazil.

Tabela 1. Parâmetros microscópios das amostras de madeira pertencentes a quatro espécies comercializados como "tauari”, retiradas de serrarias em diversos municípios do estado do Pará, norte do Brasil.

\begin{tabular}{|c|c|c|c|c|c|c|c|}
\hline Species & $\begin{array}{c}\text { Number of } \\
\text { samples }\end{array}$ & $\begin{array}{l}\text { Rays } \\
(\mathbf{m m})\end{array}$ & $\begin{array}{l}\text { Ray width } \\
(\mu \mathrm{m})\end{array}$ & $\begin{array}{c}\text { Ray width } \\
\text { (n cells) }\end{array}$ & $\begin{array}{l}\text { Ray heigth } \\
(\mu \mathrm{m})\end{array}$ & $\begin{array}{c}\text { Vessel diameter } \\
(\mu \mathrm{m})\end{array}$ & $\begin{array}{c}\begin{array}{c}\text { Vessel } \\
\left(\mathbf{n} / \mathbf{m m}^{2}\right)\end{array} \\
\end{array}$ \\
\hline \multirow{2}{*}{$\begin{array}{l}\text { Couratari } \\
\text { oblongifolia }\end{array}$} & & $5.60 \mathrm{c}$ & $71.65 \mathrm{a}$ & $2.69 \mathrm{a}$ & $633.52 \mathrm{a}$ & $209.03 \mathrm{a}$ & $2.61 \mathrm{~b}$ \\
\hline & & $(1.22)$ & (19.72) & (0.93) & (240.64) & (75.38) & $(1.21)$ \\
\hline \multirow{2}{*}{ Couratari stellata } & & $5.18 \mathrm{c}$ & $60.06 \mathrm{~b}$ & $2.62 \mathrm{a}$ & $657.91 \mathrm{a}$ & $228.95 \mathrm{a}$ & $2.56 \mathrm{~b}$ \\
\hline & & (1.46) & (12.92) & $(0.85)$ & (237.66) & $(52.50)$ & (1.04) \\
\hline
\end{tabular}

FLORESTA, Curitiba, PR, v. 50, n. 3, p. 1421 - 1429, jul/set 2020.

Santos, J. X. et.al. 


\begin{tabular}{lccccccc}
\hline $\begin{array}{l}\text { Couratari } \\
\text { guianensis }\end{array}$ & \multirow{2}{*}{$6.98 \mathrm{a}$} & $67.42 \mathrm{~b}$ & $2.75 \mathrm{a}$ & $603.3 \mathrm{a}$ & $227.08 \mathrm{a}$ & $2.25 \mathrm{~b}$ \\
& & $(1.25)$ & $(15.76)$ & $(0.90)$ & $(223.19)$ & $(51.74)$ & $(0.88)$ \\
\hline \multirow{2}{*}{ Eschweilera sp. } & \multirow{2}{*}{1} & $6.43 \mathrm{~b}$ & $47.12 \mathrm{c}$ & $2.93 \mathrm{a}$ & $653.31 \mathrm{a}$ & $221.63 \mathrm{a}$ & $3.60 \mathrm{a}$ \\
& & $(1.10)$ & $(10.93)$ & $(0.94)$ & $(255.37)$ & $(38.06)$ & $(1.52)$ \\
\hline
\end{tabular}

\section{Total}

18

Standard deviation in parentheses. Same letter in the collum do not differ by Scott-Knott test at $95 \%$ of probability. In each sample 30 dimensions were measured for microscopic analysis.

Wood from evaluated species presented mean values similar statistically for vessel diameter, ray wide (cells number) and ray height $(\mu \mathrm{m})$, confirming the problems in species discrimination, because they are similar even where quantitative data are considered (Table 1).

Species Couratari oblongifolia and Couratari stellata are not statistically different in ray frequency. The great ray frequency was observed in Couratari guianensis $(6.98 / \mathrm{mm})$ and Eschweilera sp. $(6.43 / \mathrm{mm})$. Based on classes proposed by (IAWA, 1989), all species are classified as $4-12$ rays $/ \mathrm{mm}$.

Ray wide $(\mu \mathrm{m})$ varied strongly. Greatest value was observed for Couratari oblongifolia, with $71.65 \mu \mathrm{m}$, followed by Couratari guianensis $(67.42 \mu \mathrm{m})$ and Couratari stellata $(60.06 \mu \mathrm{m})$. In Eschweilera sp., ray were narrower with $47.12 \mu \mathrm{m}$.

For mean tangential vessel diameter, (IAWA, 1989) characterize them with values above $200 \mu \mathrm{m}$. In vessel frequency, Eschweilera sp., presented great values (3.60 vessels $\left./ \mathrm{mm}^{2}\right)$, in relation to Couratari oblongifolia, Couratari stellata and Couratari guianensis that are not statistically different.

\section{DISCUSSION}

Anatomic characteristics of the species sampled in this study "tauari" were similar to those of other evaluations, such as the descriptions of Eschweilera and Couratari by Lens et al. (2007), of Couratari guianensis and Eschweilera sp. by León (2008), and of C. guianensis, C. oblongifolia and C. stellata by Bernal et al. (2011). Most of our samples "tauari” presented distinct growth rings, with a few indistinct ones, that are formed in response to environmental and climate conditions, such as precipitation (MARCATI et al., 2008). These parameters cannot be applied as a discrimination parameter between species, because it is influenced by environment, principally rain seasonality, which are related to species development, as well as in delimitation of growth rings (CALLADO et al., 2013). The samples presented diffuse porosity, solitary vessels arranged in radial multiples, with circular to oval shape. Vessel diameter and frequency are important taxonomic characteristics but are influenced by factors related to water availability and its transport (CARLQUIST, 2001).

For axial parenchyma, all species present it visible at naked eyes; predominantly in large bands or lines with until three cells. Alves and Angyalossy-Alfonso (2002) verified that trees in hot environments showed parenchyma more abundant, what is confirmed in this study with the observation of wood samples from native forests of Pará state.

Prismatic crystals were observed in the axial parenchyma of Couratari oblongifolia and Eschweilera sp. However, evaluation of frequency and type of crystals were not an objective of this study since samples are from a single region.

Based on commercial importance of genera Couratari in Amazon biome, Couratari guianensis, C. oblongifolia and $C$. stellata are on the list of the ten most marketed in the Brazilian Amazon, as sawn wood and logs (NAHUZ, 2013). However, data in System of Commerce and Transport of Forest Products in Para (SISFLORA-PA) shows a substantial commerce of logs from Couratari multiflora with 2,262 $\mathrm{m}^{3}$ in ten years only from the municipality of Tucuruí, Pará (SEMAS-PA, 2016). However, C. multiflora is considered as a lowdensity wood $\left(0.48 \mathrm{~g} / \mathrm{cm}^{3}\right)$ what reduces wood interest in comparison to other "tauari" species (CHAVE et al., 2006).

This number can be the confirmation of mistakes in identifications done in locu of "tauari" species. This trend was also observed by Pastore et al. (2011) and Soares et al. (2017), which comments the presence of many species visually similar being grouped and commercialized in brasilian Amazon. This context shows the necessity of procedures more effective for correct identification of species with regard to forest inventories destined to the approval of Sustainable Forest Management Projects (PMFS), where possibly distinct species are grouped and marketed under the same vernacular name. Consequently, PMFS procedures in the State of Pará and in the other regions of Amazon have presented serious technical and implementation problems (IBAMA, 2010). The presence in wood sold as "tauari" of Cedrela sp. and Erisma uncinatum is worrying, for it shows that species outside the Lecythidaceae are mistaken or misidentified for "tauari". Species of Cedrela are listed in

FLORESTA, Curitiba, PR, v. 50, n. 3, p. 1421 - 1429, jul/set 2020.

Santos, J. X. et.al.

ISSN eletrônico 1982-4688

1427

DOI: 10.5380/rf.v50 i3. 59399 
CITES as endangered, which highlights the importance of correct wood species identification in the supervision of wood trade.

\section{CONCLUSION}

In this study, we concluded that:

- We demonstrated that several different species, from different botanical families are marketed generically as "tauari" in Pará state. Most species belong to Lecythidaceae, but one specie of Meliaceae (Cedrela sp.) and one of Vochysiaceae (Erisma uncinatum) were also identified.

- Wood characteristics were very similar among the species of Lecythidaceae; only Couratari oblongifolia and Eschweilera sp. presented substantial structural differences, while $C$. stellata and C. guianensis were more difficult to distinguish.

- The use of a single popular name to designate several species in the wood trade in Pará generates unreliable monitoring figures for timber management, and masks the exploitation of endangered species, such as Cedrela sp.

\section{AKNOWLEDGMENTS}

We thank the staff of Museu Paraense Emílio Goeldi and Embrapa Amazônia Oriental for supplying samples and CNPq (Conselho Nacional de Desenvolvimento Científico e Tecnológico) for the research grant.

\section{REFERENCES}

ALVES, E. S.; ANGYALOSSY-ALFONSO, V. Ecological trends in the wood anatomy of some Brazilian species. II axial parenchyma, rays and fibres. IAWA Journal, Netherlands, v. 23, n. 1, p. 391 - 418, 2002.

BERNAL, R. A.; CORADIN, V.; CAMARGOS. J.; COSTA, C.; PISSARRA, J. Wood anatomy of Lecythidaceae species called tauari. IAWA Journal, Netherlands, v. 32, n. 1, p. 97 - 112, 2011.

CALlADO, C. H.; ROIG, F. A.; TOMAZELLO-FILHO, M.; BARROS, C. F. Cambial growth periodicity studies of South American woody species - a review. IAWA Journal, Netherlands, v.34, n. 3, p. 213 - 230, 2013.

CANDIAN, M.; SALES, A. Aplicação das técnicas não-destrutivas de ultra-som, vibração transversal e ondas de tensão para avaliação de madeira. Ambiente Construído, Porto Alegre, v. 9, n. 4, p. 83 - 98, 2009.

CARLQUIST, S. Comparative wood anatomy: systematic ecological and evolutionary aspects of dicotyledon wood. Berlim: Springer Verlag, 2 ed. 2001, 448 p.

CHAVE, J. C.; LANDAU, H. C. M.; BAKER, T. R.; EASDALE, T. A.; STEEGE, H. T.; WEBB, C. O. Regional and phylogenetic variation of wood density across 2,456 neotropical tree species. Ecological Applications, Washington, v. 16, p. 2356 - 2367, 2006.

CORADIN, V. T. R.; CAMARGOS, J. A. A.; PASTORE, T. C. M.; CHRISTO, A. G. Madeiras Comerciais do Brasil: Chave interativa de identificação baseada em caracteres gerais e macroscópicos. Serviço Florestal Brasileiro, Laboratório de Produtos Florestais: Brasília. CD-ROM, 2011.

FONSECA, A.; JUSTINO, M.; CARDOSO, D.; RIBEIRO, J.; SALOMÃO, R.; SOUZA, J. R. C.; VERÍSSIMO, A. Sistema de alerta de desmatamento (SAD). Belém: Boletim do desmatamento da Amazônia Legal, Imazon, 1 ed. 2017, $10 \mathrm{p}$.

FORZZA, R. C.; BAUMGRATZ, J. F. A.; BICUDO, C. E. M.; CARVALHO, J. R. A. A.; COSTA, A; COSTA, D. P.; HOPKINS, M.; LEITMAN, P. M.; LOHMANN, L. G.; MAIA, L. C.; MARTINELLI, G.; MENEZES, M.; MORIM, M. P.; COELHO, M. A. N.; PEIXOTO, A. L.; PIRANI, J. R.; PRADO, J.; QUEIROZ, L. P.; SOUZA, V. C.; STEHMANN, J. R.; SYLVESTRE, L. S.; WALTER, B. M. T.; ZAPPI, D. Catálogo das Plantas e Fungos do Brasil. Rio de Janeiro: Instituto de Pesquisas Jardim Botânico do Rio de Janeiro, 1 ed. 2010, $878 \mathrm{p}$.

GASSON, P. How precise can wood identification be? Wood Anatomy's Role in Support of the Legal Timber Trade, Especially CITES. IAWA Journal, Netherlands, v. 32, n. 2, p. 137 - 154, 2011.

IAWA COMMITTEE. List of microscopic features of hardwood identification. Netherlands: IAWA Bulletin, 3 ed. 1989, 332 p. 
IBÁ. Relatório Anual IBÁ 2016: Brazilian tree industry. Brasília: 1ed. 2016, 100 p.

IBAMA (Instituto Brasileiro de Meio Ambiente e dos Recursos Naturais Renováveis). Informação estratégica para a gestão florestal no Brasil: período 2007-2009. Brasília, 2010, 56 p.

IBAMA (Instituto Brasileiro de Meio Ambiente e dos Recursos Naturais Renováveis). Padronização da nomenclatura comercial brasileira das madeiras tropicais amazônicas. Brasília, 1991, 56 p.

LEÓN, W. J. H. Estudio anatómico de la madera en 17 especies de la familia Lecythidaceae de Venezuela. Revista Forestal, Venezolana, v. 52, n. 2, p. 213 - 225, 2008.

LENS, F.; BAAS, P.; JANSEN, S.; SMETS, E. A search for phylogenetically informative wood characters within Lecythidaceae S. L. American Journal of Botany, USA, v. 94, n. 4, p. 483 - 502, 2007.

MARCATI, C. R.; MILANEZ, C. R. D.; MACHADO, S. R. Seasonal development of secondary xylem and phloem in Schizolobium parahyba (Vell.) Blake (Leguminosae: Caesalpinioideae). Trees, Berlin, v.22, n.1, p. 3 - 12, 2008.

MARTINELLI, G.; MORAES, M. A. Livro vermelho da flora do Brasil. Rio de Janeiro: CNCFlora Instituto de Pesquisa Jardim Botânico do Rio de Janeiro, 1 ed. 2013, 1100 p.

MORI, S. Diversificação e conservação das Lecythidaceae neotropicais. Acta Botanica Brasilica, Belo Horizonte-MG, v. 4, n. 1, p. 45 - 68, 1990.

NAHUZ, M. A. R. Madeiras Brasileiras Pará a Construção Civil. São Paulo: IPT, 2 ed. 2013, 104 p.

PASTORE, T. C. M.; BRAGA, J. W. B.; CORADIN, V. T. R. Near infrared spectroscopy (NIRS) as a potential tool for monitoring trade of similar woods: Discrimination of true mahogany, cedar, andiroba, and curupixá. Holzforschung, Berlin, v. 65, n. 1, p. 73 - 80, 2011.

PAULA, J. E.; COSTA, K. P. Densidade da madeira de 932 espécies nativas do Brasil. Porto Alegre: Cinco Continentes ,1 ed. 2011, 248 p.

PROCÓPIO, L. C.; SECCO, R. S. A importância da identificação botânica nos inventários florestais: o exemplo do "tauari" (Couratari spp. e Cariniana spp. - Lecythidaceae) em duas áreas manejadas no Estado do Pará. Acta Amazonica, Manaus, v. 38, n. 1, p. 31 - 44, 2008.

SEMAS-PA. Relatório de extração e movimentação de toras de madeiras nativas: período de 01/01/2006 a 21/02/2016. Disponível em:<https://monitoramento.semas.pa.gov.br/sisflora/relatorios.html> Acesso em: 27 ago. 2017.

SOARES, L. F.; SILVA, D. C.; BERGO, M. C. J.; CORADIN, V. T. R.; BRAGA, J. W. B.; PASTORE, T. C. M. Avaliação de espectrômetro NIR portátil e PLS-DA para a discriminação de seis espécies similares de madeira Amazônicas. Química Nova, São Paulo, v. 40, n. 4, p. 418 - 426, 2017. 